\title{
HOW CREATIVE PROFESSIONALS RESHAPE THE HISTORIC CITY. THE PERSPECTIVE OF ARCHITECTS AS MANAGERS OF COWORKING SPACES IN VILLANOVA DISTRICT, CAGLIARI CITY
}

\author{
Alessia USAI \\ Department of Civil and Environmental Engineering and Architecture, University of Cagliari, ITALY \\ alessiausai@gmail.com \\ DOI: http://doi.org/10.23740/TID120192
}

\section{ABSTRACT}

Professionals and firms of the creative and cultural sector contribute to the creation of business incubators, fablabs and coworking spaces in the historic city, often benefiting from public support. Our paper deals with these creative spaces. It investigates the relationship that architects, as creative professionals and coworking managers, establish with the historic city, the workplace, and the planning and protection rules on buildings. In particular, starting from a research on coworking spaces in the historic District of Villanova, in Cagliari City (Sardinia, IT), this paper critically reflects on the current tools and methods used to map and manage creative spaces in the historic city, making some proposals for their improvement and enforcement in urban regeneration strategies.

Keywords: urban regeneration, creative spaces, Sardinia, Italy

\section{INTRODUCTION}

The city - intended as the archetype of a specific and well-established form of social organization - has always been recognised as a driver of creativity and innovation. The reasons for its success lie in its ability to attract the basic development functions and to re-design its physical structure, by including all the infrastructure, buildings and spaces that every historical period requires. Therefore, creativity is not an exclusive and distinctive trait of the present and future city, since it is explicitly pursued through methods typical of each development stage (Fusco Girard, Baycan, and Nijkamp, 2016).

On the contemporary scene, creativity is sought and pursued through the spatial and socioeconomic regeneration of the historic city, due to: a visual identity that facilitates the linkage between the creatives and the local business community; a wide offer of brownfield sites; the cultural and tourist appeal which attracts the foreign (Stevenson, 2014; Hutton, 2016; Bell and Jayne, 2017).

Structural changes within the urban labour market (increasing individualism and social insulation of workers) and digital technologies (home working, remote and mobile working, etc.) have led to a new spatial distribution of work and to a new range of workplaces: homebased businesses (HBB), semi-public "Third Spaces" (cafés, libraries) or shared workspaces (Brown, 2017; Merkel, 2015). Capdevila (2013) defines the latter as localised spaces of collaborative innovation (LSCI), where knowledge communities meet to collectively innovate. The author identifies the following typologies: hacker spaces, maker spaces, Living Labs, Fab Labs and co-working spaces. Co-working spaces show a clear focus on the economic aspect, but with a particular attention to professional collaborations and community-building 
(especially in case of coworking managers), by pursuing a mix of projects, some of them proposed and funded by institutions, and some by their users (Capdevila, 2013).

HBBs, "Third Spaces" and LSCls represent the workplaces of creative professionals and they can be grouped under the broader category of "creative spaces", as we refer to in our study.

Creative spaces can influence urban development encouraging restructuring and, in some cases, gentrification processes. For instance, Merkel (2015) points out the ambivalent role of coworking being "pioneers", raising the symbolic value of a particular area and becoming victims of gentrification processes at the same time, even in the historic city centre.

Creative professionals and companies operating in the inner city neighbourhoods contribute to the birth of business incubators, fablabs and coworking, but they also are involved in community-led initiatives, often with the support of the public actors (Mariotti, Carolina, and Di Vita, 2017). Despite this, little is still known about their approach to the historic city and the workplace in relation to the urban planning and protection rules which govern the city transformation, especially when the creators of these creative spaces are planners and architects and, besides promoting regeneration interventions, also benefiting from them.

How creative professionals experience and change the historic city. Answers from diverse disciplines

The relational models underlying the economic and social components of the historic city require new answers about the typical symbolism of the city and its manifestations in place making, both official (or government-led) and community driven (Fusco Girard, Baycan, and Nijkamp, 2016).

In public policies, there is a need for collective forms of representation for creative professionals, who still struggle to be recognised as a "class", as evidenced by Richard Florida (2002). On the one hand, this issue does not allow the public subject to effectively catch and grasp the demands of this particular social group, and, on the other hand, it prevents an adequate lobbying action by the creative professionals when it comes to the definition of the urban agenda (Manzella, 2017).

Similarly, in scientific research and professional practice, a new "field activity" is required to better understand the housing and location choices of creative professionals and, consequently, to derive from the ongoing experiments the methodological and instrumental aspects through which the minimum standards for housing and public services should be reestablished.

Various disciplines are facing this problem. In the economic field, for example, the creative supply is studied focusing on the localization and aggregation of companies within the urban fabric, and assessing their impact in terms of urban segregation and conflict at local scale (Roodhouse, 2010; D'Ovidio, 2016; Hutton, 2016; Florida, 2017; Scott, 2018). As for the designoriented disciplines (i.e. performing arts, urban design and architecture), the research examines the relationship between the individual and the residence/working spaces, as well as with public spaces, in static (stay) and dynamic (movement) terms (Evans, 2001; City Form Lab, 2014; Sevtsuk and Kalvo, 2017). At the urban planning level, the research on public space has recently gained a new impulse thanks to the creative regeneration of former industrial facilities and abandoned public buildings in the historic city (Bianchetti, 2016; Usai, 2016; Bruzzese, Gerosa, and Tamini, 2017; Di Lascio and Giglioni, 2017.) 
Regenerating the historic city through creative spaces: the contribution of urban planning

In regeneration strategies focused on the conversion of historic buildings into "creative spaces", the Urban Planning discipline provides hybrid methodologies in which planning tools (technical reports, graphic drawings, statistical data, etc.) and the tools of social sciences (questionnaires, interviews, etc.) are used jointly according to an urban-industrial observational and ethnographic approach taken from Human Geography (Hutton, 2016). These methods include the following steps (Usai, 2016; Colavitti, 2018; Colavitti, Serra, and Usai, 2018):

-Identification of a reference statistical classification for cultural and creative enterprises (UNESCO, KEA, etc.) and its adaptation to the local context;

-Recognition of cultural and creative enterprises with respect to the general companies operating in the historic city (sector and location of the registered office/production facility);

-Production of maps to highlight the presence of agglomerations of companies in the urban fabric and the spatial factors that influence the location and housing choices of creative professionals in relation to the rules fixed by the current planning and/or by public projects;

-Validation of the data pointed out by the cartography through a direct comparison with creative professionals: by means of questionnaires and interviews, the "qualitative" aspects of the historic city and the working environment, which are particularly relevant for creative professionals and their satisfaction in relation to the context conditions, are assessed;

-Definition of a coordinated intervention strategy including the introduction of new functions and creative spaces into the historic city according to the constraints imposed by the existing plans and projects.

Similar experiments were carried out in Genoa with a European project called Creative Cities, and in Milan with the Urban Commerce Districts (Usai, 2016; Bruzzese, Gerosa, and Tamini, 2017). However, these experiences marginally consider the contribution of architects and planners as the first founders of creative spaces in the historic city (i.e. the cases when the technical professional, besides promoting creative regeneration interventions, also benefit from them). This research perspective is particularly interesting, since it helps assess to what extent the architects responsible for the preservation of the historic city recognise themselves as "creative professionals", as well as define their degree of confidence when it comes to managing the impacts of the cultural and creative economics on the urban fabric through the methods described above.

Our contribution relies on this perspective and poses a critical reflection on the methods used today for the mapping and analysis of creative spaces in the historic city starting from a research which involved architecture students and architects who manage coworking spaces in the historic District of Villanova, in Cagliari City (Sardinia, IT), a quarter which was chosen as a case study due to an incomplete or still ongoing renovation and gentrification process of particular interest for our research aim.

This paper is structured as follows. The first section above illustrates the problematic understating of creative professionals as agents of change in the historic city and how different disciplines, including Urban Planning, try to cover this knowledge gap. The second section illustrates the reasons behind the choice of Villanova District as a case study. In particular, it provides a general picture of challenges and issues posed to the district by urban regeneration interventions and creative spaces, above all compared to the other historic neighbourhoods in the city centre. The third section presents the methodological framework applied to the case 
study. The research outcomes are discussed in the last two sections, which critically reflect on the methods currently used to map and manage creative spaces in the historic city, advancing some proposals for their improvement and enforcement in urban regeneration strategies.

\section{THE CASE STUDY. CREATIVE AND COWORKING SPACES IN THE HISTORIC DISTRICT OF VILLANOVA IN CAGLIARI CITY (SARDINIA, IT)}

Cagliari City is the administrative capital of Sardinia Island, an autonomous region of Italy. It covers an area of around $86.05 \mathrm{~km}^{2}$ with 154,267 inhabitants (2018). The city centre is made of four neighbourhoods: Castello, Marina, Stampace and Villanova. Castello is the walled town form which the city has developed since the $13^{\text {th }}$ century, while Marina, Stampace and Villanova represent the historic suburbs (see Figure 1 ). In the $20^{\text {th }}$ century Castello lost the defensive and administrative function, becoming a cultural centre and a residential area. Marina, a former quarter of fishermen and craftsmen, has acquired a tourist function, while Stampace and Villanova have maintained a productive, commercial and artisanal identity and they are the most populous districts with 6,849 and 6,100 inhabitants in 2018, respectively (while Castello has 1,406 inhabitants and Marina has 2,739) (Comune di Cagliari, 2018).

Among the four historical neighbourhoods, Villanova is the most recent: its establishment is associated with the construction of the convent of San Domenico in the $13^{\text {th }}$ century. Later, the building stretched along the streets that connect San Domenico with the $14^{\text {th }}$ century church of San Giovanni, following the land morphology (see Figure 1). The secondary road network developed perpendicularly to the main routes, while the city walls had defined the district boundaries until the $19^{\text {th }}$ century. The result is an elongated "chessboard" pattern, built on hilly terraces and characterised by buildings constructed on long and narrow parcels, with two entrances, one upstream and the other downstream. The squares of San Giacomo and San Domenico, overlooked by the homonymous churches, are the only public spaces in the district. The original building structure was preserved in the area included between the border of Castello District and via Garibaldi and Bacaredda, although it bears the signs of the bombing in 1943. From the post-war period up to 2000 , the urban expansion towards via Sonnino and via Dante was encouraged, therefore the district has been involved in the regeneration processes only marginally (see Figure 2).

The situation changed in 2007, after the reconstruction of the road pavement, the renovation of Via Sulis as a shopping street, the creation of a restricted-traffic zone and the pedestrianization of the main streets. In 2015, new projects were submitted by the Detailed Plan for the City Centre, ${ }^{1}$ some of which are under construction: tourist-cultural itineraries connecting the surrounding historic districts, creation of green spaces along the district boundaries and in Piazza San Domenico, re-construction of urban scenes in the main public spaces, re-development of the municipal roads and street, recovery of the former tobacco factory (Italian: Manifattura Tabacchi) as the "City's creative hub", also in relation to its proximity to the touristic District of Marina (see Table 1). In the last few years (2015-2018),

${ }^{1}$ The Detailed Plan for the City Centre was adopted with Resolution no. 52/2015. Later, the City Council partially re-approved the plan with Resolution no. 41/2016. The prescriptions in the resolution for conservation and renovation areas entered into force on 19/01/2017. For the other areas, including those to which class III has been attributed (transformation), it is specified that the Detailed Plan is not effective yet; therefore, the former Framework Plan for the City Centre and the protection measures pursuant to Law no. 1902/1952 shall apply for transformation areas. For further information on the plan: https://www.comune.cagliari.it/portale/it/at18_ppcs.page 
various coworking spaces were established in the neighbourhood, managed by architects or service professionals connected to the world of architecture (Landis, 2017).

These events modified the socio-economic fabric of the district. A significant turnover in population occurred, especially due to the arrival of new migrants in the poorly renovated areas of the district (where the housing prices are low) and, to a lesser extent, to the arrival of a "new middle class" in the refurbished areas. The old shops were partially replaced by coworking premises, art galleries and luxury boutiques in Via Sulis. However, the most evident changes are represented by the B\&Bs built after the pedestrianization, as well as by the corner shops managed by immigrants (retail trade, restaurants, and handcraft).

To sum up, the renovation interventions modified the historic identity of Villanova, leading to a "hybrid" district, where residents, new inhabitants and migrants, luxury boutiques and old shops coexist with some conflicts. This is an example of incomplete or still ongoing gentrification and, therefore, it may help study the role played by architects and planners for the creative and cultural transformation of the historical buildings, unlike the other historic districts of Cagliari. For this reason, Villanova has been chosen as a case study for this research.

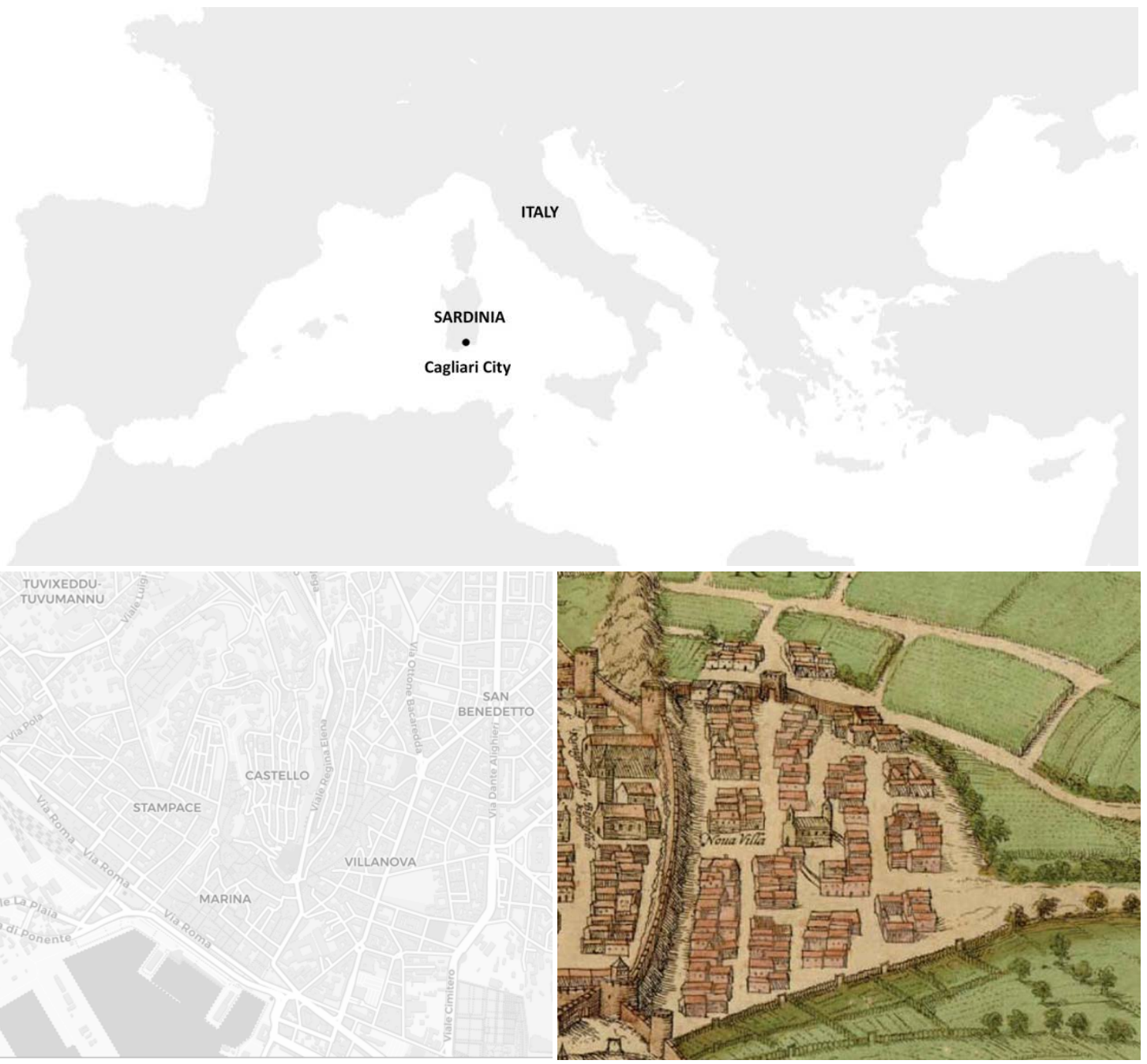

Figure 1: Cagliari City - the geographical context, a view of the city centre and a view of Villanova District in the Cosmographia Universalis by Sebastian Münster (1550)

Source: Elaboration by the author on Cagliari City WebGIS and Detailed Plan for its City Centre 


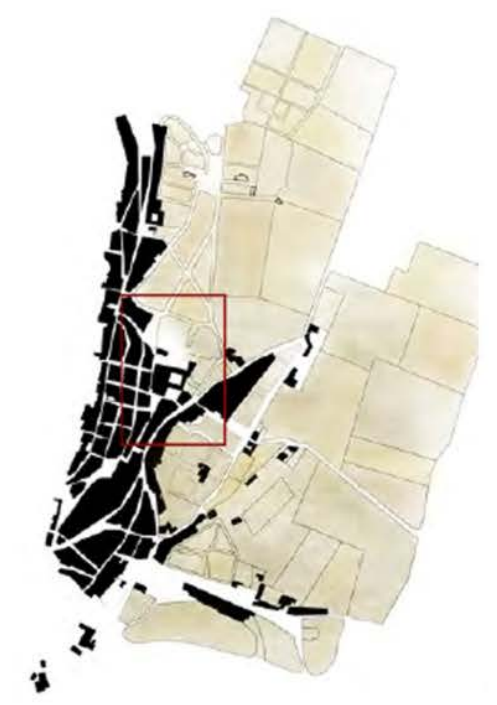

1800-1850:

Villanova district and San Domenico complex (in the red rectangle)

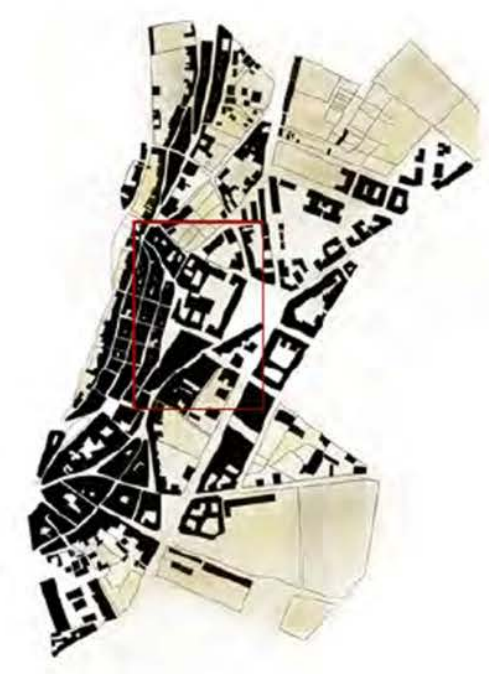

1943:

Factories and residences that took the place of open fields, are damaged by the bombing

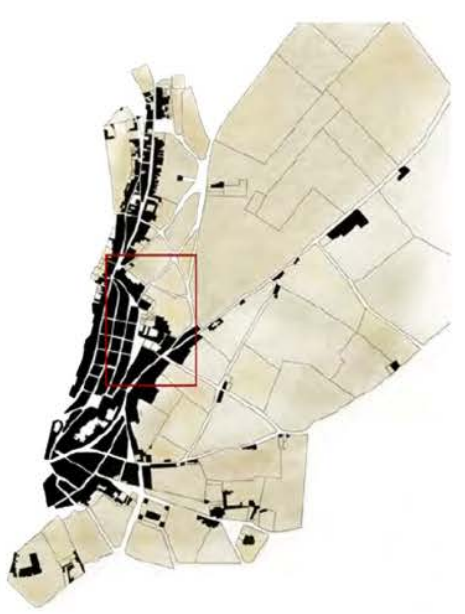

1850-1900:

Dismissal of the city walls and urban development along the main roads

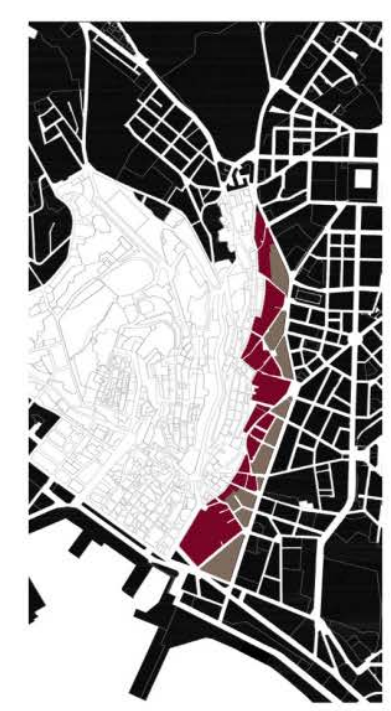

1950-2000:

De-industrialisation leaves spaces and buildings in need of recovery (in light grey)

Figure 2: Evolution of Villanova District in the last two centuries 
Table 1: Main events occurred in the Villanova District from 2003 to today

\begin{tabular}{|l|l|}
\hline Year & Key facts \\
\hline $\mathbf{2 0 0 3 - 2 0 0 5}$ & $\begin{array}{l}\text { Tourist route "Città Regie" project: renovation of Piazza San Domenico; } \\
\text { restoration of the embankment promenade; underground car parking in Viale } \\
\text { Regina Elena; functional refurbishing of the Municipal Gallery of the Public } \\
\text { Gardens. }\end{array}$ \\
\hline $\mathbf{2 0 0 7 - 2 0 1 0}$ & Fixing of underground utilities and road pavement (Cagliari City). \\
\hline $\mathbf{2 0 1 0}$ & $\begin{array}{l}\text { Renovation of Via Sulis as a shopping street: some buildings are purchased } \\
\text { and renovated to be used as luxury boutiques and housing units (private real } \\
\text { estate transactions carried out by a local entrepreneur). }\end{array}$ \\
\hline $\mathbf{2 0 1 0}$ & $\begin{array}{l}\text { The Novasulis consortium is established and deals with the organization and } \\
\text { promotion of events dedicated to art, fashion, culture and design in the } \\
\text { district (Retailers of Via Sulis). }\end{array}$ \\
\hline $\mathbf{2 0 1 0}$ & $\begin{array}{l}\text { The "Abitanti di Villanova" Committee is created with the purpose of } \\
\text { promoting residents' requests and needs in terms of renovation of the district } \\
\text { (Villanova residents). }\end{array}$ \\
\hline $\mathbf{2 0 1 5}$ & $\begin{array}{l}\text { The restricted-traffic area is implemented from 9.00 pm to 7.00 am and from } \\
\text { 3.30 pm to 5.00 pm (Cagliari City). }\end{array}$ \\
\hline $\mathbf{2 0 1 6 - ( 2 0 1 9 )}$ & $\begin{array}{l}\text { Design projects of the Detailed Plan for the City Centre (Cagliari City). } \\
\text { Recovery and opening of the former Manifattura Tabacchi to be used as a } \\
\text { fablab and incubator of new businesses (Sardegna Ricerche - Regional Agency } \\
\text { on Research and Innovation). }\end{array}$ \\
\hline
\end{tabular}

\section{METHODOLOGY}

The research aim was the experimentation of the methods currently used for the definition of regeneration strategies based on creative spaces in Villanova, by a group of architecture students of the University of Cagliari. ${ }^{2}$ The study was aimed at:

- introducing the "future architects" to map and design creative spaces in urban contexts (educational purpose): for this reason, the students were involved directly in the interviews with coworking managers;

- evaluate if and how architects recognise themselves as "creative professionals" and discover their relationship with the historic city and workplace (scientific purpose): for this reason, the students were interviewed before the beginning of the course, with the same questionnaire used for the coworking managers in Villanova (who were architects, too), except for the questions related to the conduction of the business activity.

${ }^{2}$ The activities described in the following paper were carried out during the course entitled "The Creative City. Methods and Tools to Support Urban Policies" ("La Città Creativa. Metodi e strumenti di supporto alle politiche urbane"), which lasted for 20 hours and involved the students of the degree course in Architecture Science, as well as those of the $2^{\text {nd }}$ level degree course in Architecture at the University of Cagliari in the Academic Year 2017/2018. 
Initially, the structured questionnaire was submitted to six students to assess their familiarity with the basic concepts of creative economy and their self-recognition as future "creative professionals". Later, they were trained on the same topics through targeted workshops and were asked to develop renovation strategies for Villanova, through the creation of coworking premises for architects and designers.

Thus the groups experimented and simulated the various steps of the methods described. Firstly, they broke down the creative companies by sector based on a specific statistical framework developed by the author for Sardinia region. Considering that it was a simulation for educational purposes, the students were given a simplified version of the framework, but fully respondent to the national classification of economic activities (named Ateco 2007) and the main classification systems for Cultural and Creative Industries (CCls) available as of 2017, in Italy (see Table 2). The framework had also an additional section on tourism, considering the importance of this economic sector in Sardinia region (see Table 3).

Table 2: Reports at the base of the statistical framework adopted in the study

\begin{tabular}{|l|l|l|}
\hline Year & Report & Description \\
\hline 2007 & $\begin{array}{l}\text { MiBAC, Istituto Tagliacarne, 2007. } \\
\text { Le attività economiche collegate } \\
\text { alla valorizzazione del patrimonio } \\
\text { culturale. Roma: Istituto } \\
\text { Tagliacarne. }\end{array}$ & $\begin{array}{l}\text { Statistical report on the economic } \\
\text { value of cultural heritage issued by the } \\
\text { Italian Ministry of Culture. }\end{array}$ \\
\hline 2009 & $\begin{array}{l}\text { MiBAC, 2009. Libro bianco sulla } \\
\text { creatività, MiBAC - Commissione } \\
\text { sulla Creatività e Produzione di } \\
\text { Cultura in Italia (Walter Santagata). } \\
\text { Roma: MiBACT. }\end{array}$ & $\begin{array}{l}\text { Italian White Book on Creativity issued } \\
\text { by the Ministry of Culture and edited } \\
\text { by Walter Santagata. }\end{array}$ \\
\cline { 2 - 4 } & $\begin{array}{l}\text { Unioncamere, Istituto Tagliacarne, } \\
\text { 2009. II sistema economico } \\
\text { integrato dei beni culturali. Roma: } \\
\text { Istituto Tagliacarne. }\end{array}$ & $\begin{array}{l}\text { Statistical report on the economic } \\
\text { value of cultural heritage issued by the } \\
\text { Italian Union of the Chambers of } \\
\text { Commerce. }\end{array}$ \\
\hline 2010 & $\begin{array}{l}\text { Cicerchia A. (a cura di), 2010. } \\
\text { Economia della cultura e giovani, } \\
\text { rapporto di ricerca (progetto Italia } \\
\text { Creativa Min. Gioventù - vol. 2. } \\
\text { Roma: Edizioni ANCI ComuniCare. }\end{array}$ & $\begin{array}{l}\text { Statistical report on youth and the } \\
\text { creative economy issued by the } \\
\text { Ministry of Youth as a result of a } \\
\text { research project. }\end{array}$ \\
\hline 2016-today & $\begin{array}{l}\text { Rapporti annuali di Unioncamere e } \\
\text { Symbola pubblicati ne "I quaderni } \\
\text { di Symbola". }\end{array}$ & $\begin{array}{l}\text { Yearly reports on creative economy } \\
\text { issued by the Italian Union of the } \\
\text { Chambers of Commerce. }\end{array}$ \\
\hline 2013-today & $\begin{array}{l}\text { Rapporti annuali di Federculture. } \\
\text { MiBACT e Ernest\&Young. }\end{array}$ & $\begin{array}{l}\text { Yearly reports on cultural economy } \\
\text { issued by the Italian Federation of } \\
\text { Companies and Organizations for the } \\
\text { Management of Culture, Tourism, } \\
\text { Sportand Leisure. }\end{array}$ \\
\hline
\end{tabular}


Later, the students geolocalised the creative companies operating in Villanova and drew up a thematic map through a GIS software (Figure 3).

Table 3: Statistical framework in the study: breakdown of CCls in macro-sectors and sectors

\begin{tabular}{|c|c|}
\hline Macro-sector & Sectors \\
\hline \multirow{3}{*}{ Creative industry } & Architecture \\
\hline & Communication and branding, advertising \\
\hline & Fashion, design and industrial production, craftsmanship \\
\hline \multirow{5}{*}{ Cultural industry } & Publishing (books and printing) \\
\hline & Music \\
\hline & Audio-visual productions (film, video, radio, TV) \\
\hline & Advertising \\
\hline & Multimedia (computer and software, including video games) \\
\hline \multirow{4}{*}{ Food industry } & Cultivations for the agri-food sector (excluding the growing of biomass) \\
\hline & Production, processing, preservation and packaging of food products \\
\hline & Typical and traditional food and wine productions \\
\hline & Retail sale of food products - including typical products \\
\hline \multirow{2}{*}{ Tourism industry } & Cultural and naturalistic tourism \\
\hline & Food and wine tourism, in-house catering and accommodation \\
\hline \multirow{3}{*}{ Cultural heritage } & $\begin{array}{l}\text { Museums, archives, libraries, art galleries, cultural and landscape } \\
\text { heritage management activities }\end{array}$ \\
\hline & $\begin{array}{l}\text { Cultural activities and events (visual arts, entertainment - performing } \\
\text { arts, conferences, fairs) }\end{array}$ \\
\hline & $\begin{array}{l}\text { Activities relating to "human resources" (training, scientific research, } \\
\text { employment services, philanthropy) }\end{array}$ \\
\hline
\end{tabular}

After a critical reflection on the localisation choices of the companies, the students interviewed the managers of the four coworking premises in the district, of which three were private initiatives and the remaining one was publicly managed. Although the number may be negligible, the sample accounts for $100 \%$ of the coworking spaces in the district and for $100 \%$ of the LSCls led by architects in the same area. As for the private coworking premises, two were led by young architects and one by a service company specializing in design and international cooperation. Two coworking realities were in the heart of Villanova, while the others were located at its margins, respectively towards the Marina and the hinterland.

The four interviews were based on a questionnaire whose structure was defined and adapted according to the suggestions of the same students. The questions on the environmental and location factors relevant for creative professionals were defined according to the results of the EU Project Creative Cities (Usai, 2016, pp. 120-125) and the case studies in Roodhouse (2010, pp. 173-186), City Form Lab (2014), Stevens (2015), Hutton (2016, pp. 259-265), Sevtsuk and Kalvo (2017), and Bruzzese, Gerosa, and Tamini (2017). 
Through coding techniques, students then focused on the transcription of the interviews, as well as on the communicative material produced by each coworking (flyers, web or social media pages, regulations for the users).

At the end of the research, a round table was held where the students discussed the recognition of the creative professionals of Cagliari as a "category", their relationship with the historic city and with the buildings chosen as their working place, the constraints and the plans governing any building intervention, their preferred urban environment factors and the impact of "creative spaces" on the real estate market.

\section{RESULTS AND DISCUSSION}

The future architects and coworking managers of Villanova were interested in the research topics and, in general, in the issues concerning cultural and creative economy, which were almost totally new to them. Nevertheless, the questionnaires show a common idea of "creative city" (i.e. a city characterised by significant flows, exchanges and relations between the productive networks, the single companies and the local creative talents). Therefore, an ecosystem-based approach focused on relationships and the organizational aspects is preferred, since it takes into account both businesses and individuals and adopts a critical attitude towards the people-oriented renovation strategies targeted at the "creative class" (Florida, 2002).

Different opinions were highlighted in relation to the role of architects and urban planners for the transformation of the historic city: on one hand, coworking managers considered architecture a "very present" sector in the city centre, preceded only by tourism, while, on the other hand, students mentioned training, scientific research and cultural heritage activities among the most present initiatives in the city centre, and assigned a secondary role to architecture. This is probably due to the different ways in which the city is experienced by the two target groups: students often attend the university facilities in the city centre, while coworking managers are in close contact with technical professionals and their firms.

In this regard, it is worth mentioning the reflection of a coworking manager who suggested investigating the external dimension of creative spaces (managers and users), in addition to the internal ones, namely focusing on the point of view of the retailers and restaurant owners who worked in the surrounding area, in order to better coordinate events and opening times. This reflection implies an in-depth knowledge of the dynamics within the district as well as the recognition of architects and artists as creators of the common spaces. However, certain mistrust is observed among creative entrepreneurs and the public administration: all the private managers, in fact, have described coworking as a "bottom-up" activity to which public programming is "poorly relevant", while public coworking managers provided a contrary answer (a "top-down" activity where public programming is very relevant.)

The coworking managers also added precise information to the characteristics that a historic building should have had to become a working place. The relevant architectural features include (in order of importance): direct accessibility from the street, the presence of various rooms, the renovation year, the building type, and the size of the working spaces. Sharing the working place with other companies is the only factor regarded as "very relevant". 


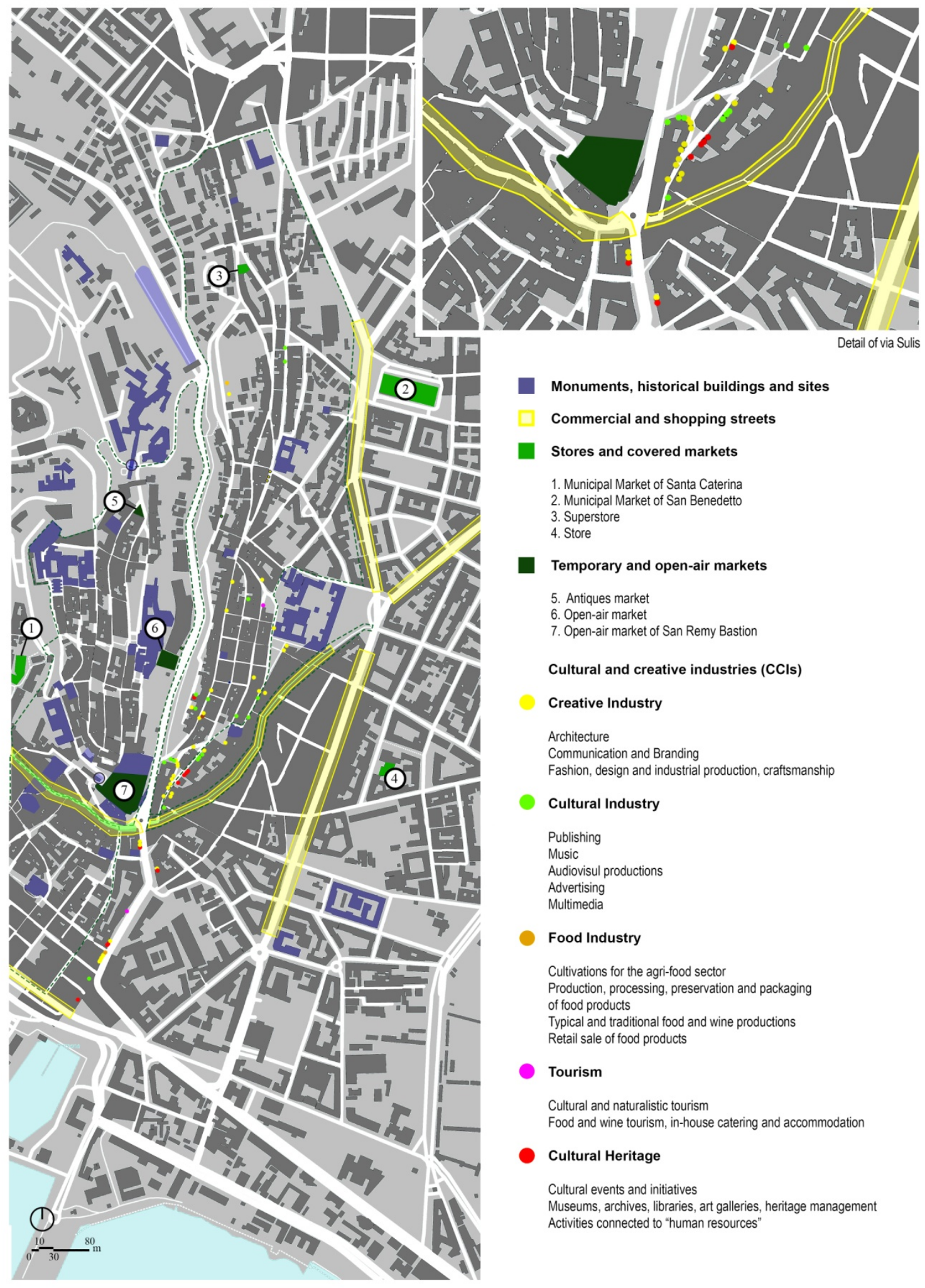

Figure 3: Map of creative enterprises as of 2015, based on data taken from the Company Register of the Chamber of Commerce of Cagliari 

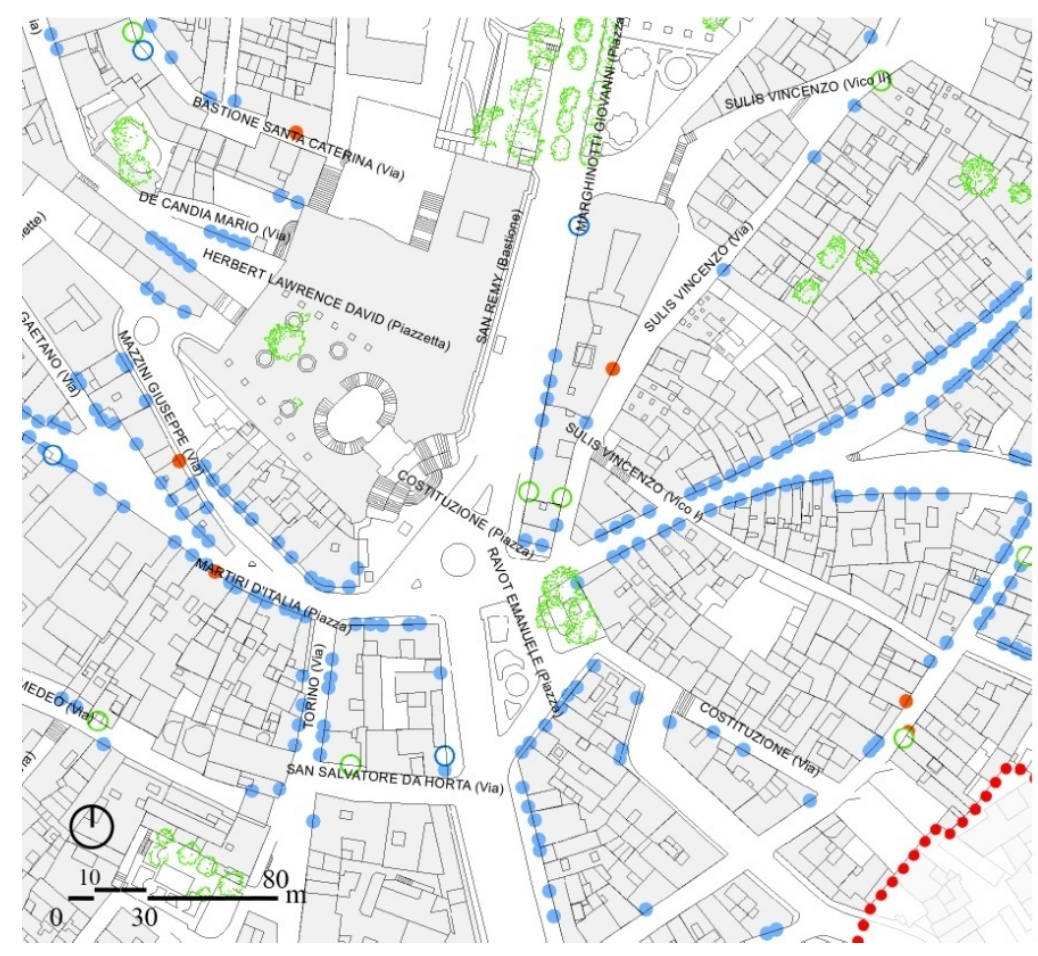

\section{:....: Historic Centre Boundery}

Craft activities

Commercial activities

Figure 4: Map of the commercial businesses as of 2015 in the Detailed Plan for the City Centre. Considering the business locations, the map shows a different picture of Via Sulis

compared to Figure 3

Source: Detailed Plan for the City Centre (Cagliari City)

Other "relevant" factors are the proximity to public transport services for accessibility purposes and the average monthly rent in relation to the environmental context. The average rent per square meter was directly assessed, where possible. In the other cases, it was calculated as follows: ( $\mathrm{n}$ workstations $\mathrm{x}$ monthly fee in $€$ per workstation) / (Surface covered by the coworking workstations in $\% x$ total surface of the site). In this regard, the average monthly rent per square meter for coworking premises compared to the one for the most similar building type in the homogeneous territorial area (OMI area) in the $2^{\text {nd }}$ half of 2018 was:

- equal or even lower for publicly managed coworking premises, because there was a fixed rent which was established after a market survey;

- slightly higher for privately managed coworking spaces situated at the northern margin of the district, in an area regarded as a suburb characterised by post-war buildings;

- three-four times higher for coworking premises located in the heart of the old quarter, far from Via Sulis, but hosted in prestigious or renovated residential buildings with special attention to interior design.

Therefore, the location choices of the coworking managers in Villanova depend on the rent, the internal characteristics of the buildings (size and divisibility), as well as on their immediate availability (last renovation year), over other aspects, such as the presence of green areas, common spaces and collective services, which are usually mentioned among the urban quality standards that creative professionals cannot give up. The map drawn up by the students confirms this trend. It shows a concentration of companies (clusters) in the most prestigious areas, in particular in Via Sulis, and in some buildings near the Marina District, besides 
accommodation facilities, restaurant and shops, as represented in the Detailed Plan for the City Centre (compare Figure 3 and Figure 4). The map also shows a remarkable but scattered presence of creative and cultural enterprises along Viale San Vincenzo, Via La Vega and Via Giardini, all these roads connecting Villanova with the northern area of Cagliari. These creative spaces are hosted in recent large and divisible buildings, with a reasonable average rent able to attract both those professionals who open their first coworking and the already wellestablished managers who address young customers with limited financial capacities. The special attention paid to the choice of the spaces and to the customers is confirmed by the sharing of urban planning regulations, as well as of the constraints which coworking managers had to face upon the opening or in the daily management of their business, although, as stated by themselves, the interventions often included only extraordinary or ordinary maintenance activities and the changes in the interior furniture.

\section{CONCLUSIONS}

In Cagliari City, coworking sites and other types of creative spaces (fablab, talent garden, etc.) are young and thriving realities with great development potential in the field of technological innovation, a relevant economic sector for the Metropolitan Area under construction. The case study of Villanova may increase the knowledge about the role played by creative professionals as a social group and which urban policies on a metropolitan scale should be taken into account.

Obviously, this was a pilot experience aimed at assessing a certain method and, consequently, it entails some limits deriving from a restricted field of investigation (the district) and a limited target (coworking managers operating in the field of Architecture and Design). However, this study highlights some criticalities in the mapping techniques and in the interviews, suggesting interesting ideas to improve the research method, such as, for example, the need to consider also the point of view of the customers and shops near the creative spaces. These aspects will be examined in the following phases of our research, which will focus on other historical districts, on the contemporary city and the hinterland, also distinguishing between local structures and those included in the national/international networks of coworking spaces.

The creative renovation of Villanova relied on an ecosystem-based approach, which considered the needs of creative companies and opposed estate operations addressing the new urban elites, in line with what R. Florida (2017) recently called "winner-take-all urbanism".

This attitude also characterises the relationship with the public actors. This mistrust is justified by the poor involvement of the citizens in the past interventions, as well as in the constant changes in the socio-economic fabric which - together with the increasing rents - confirm the neutrality of public action with respect to the ongoing gentrification. From this point of view, the managers of creative spaces, both private and public, expressed their willingness to expand their cooperation with the inhabitants through activities involving public places.

This is a weak but encouraging signal attesting the removal of the obstacles that currently stand between the creative professionals of the historic city and the desire to establish forms of collective representation to actively take part in the future urban agenda. 


\section{Acknowledgement}

The author thanks to students Alice Bardino, Margherita Cannas, Mauro Madeddu, Enrico Maria Mattana, Alessandro Murru and Riccardo Orrù, who attended the course "The Creative City. Methods and Instruments to Support Urban Policies" ("La Città Creativa. Metodi e strumenti di supporto alle politiche urbane"), in 2017/2018 academic year, for their support and consent to use map in Figure 3 which they authored.

\section{REFERENCES}

BELL, D., \& JAYNE, M. (eds.) (2017). City of Quarters: Urban Villages in the Contemporary City. London: Routledge.

BIANCHETTI, C. (2016). Spazi che contato: il progetto urbanistico in epoca neoliberale [Spaces That Count: The Urban Project in the Neoliberal Era]. Roma: Donzelli.

BROWN, J. (2017). Curating the "Third Place"? Coworking and the Mediation of Creativity. Geoforum, 82, 112-126.

BRUZZESE, A., GEROSA, G., \& TAMINI, L. (2017). Spazio pubblico e attrattività urbana. L'isola e le sue piazze [Public Space and Urban Attractiveness: Isola District and Its Squares]. Milano: Mondadori.

CAPDEVILA, I. (2013). Typologies of Localized Spaces of Collaborative Innovation. Paris: School of Business.

CITY FORM LAB (2014). Urban Network Analysis: City Form Lab's Powerful New Tools for the Analysis of Urban Activity. Evidence Based Design Journal - EBDJ, August 2014.

COLAVITTI, A.M. (2018). Urban Heritage Management Planning with History. Cham-Switzerland: Springer.

COLAVITTI, A.M., SERRA, S., \& USAI, A. (2018). Locus amoenus. Pianificare il patrimonio culturale per una nuova geografia dello sviluppo [Locus amoenus. Plannning of Cultural Heritage for a New Geography of Development]. Firenze: Altralinea.

COMUNE DI CAGLIARI (2018). Atlante demografico di Cagliari 2018 [Demographic Atlas of Cagliari City]. Cagliari: Comune di Cagliari Servizio Innovazione Tecnologica e Sistemi Informatici.

DI LASCIO, F., \& GIGLIONI, F. (eds.) (2017). La rigenerazione di beni e spazi urbani. Contributo al diritto della cittò [Urban Regeneration of Public Assets and Spaces. Contribution to the "Right to the City"]. II Mulino: Bologna.

D'OVIDIO, M. (2016). The Creative City Does Not Exist. Critical Essays on the Creative and Cultural Economy of Cities. Milano: Ledizioni.

EVANS, G. (2001). Cultural Planning: An Urban Renaissance? London: Routledge.

FLORIDA, R. (2002) The Rise of the Creative Class, and How It Is Transforming Work, Leisure, Community and Everyday Life. New York: Basic Books.

FLORIDA, R. (2017). The New Urban Crisis: How Our Cities Are Increasing Inequality, Deepening Segregation, and Failing the Middle Class and What We Can Do about It. New York: Basic Books.

FUSCO GIRARD, L., BAYCAN, T., \& NIJKAMP, P. (eds.) (2016). Sustainable City and Creativity: Promoting Creative Urban Initiatives. London and New York: Routledge.

HUTTON, T.A. (2016). Cities and the Cultural Economy. London and New York: Routledge.

LANDIS, F. (2017). Parola d'ordine: condivisione. Cagliari come Milano e si moltiplicano in centro storico gli spazi di "coworking", Vistanet - Quotidiano on line, 21 luglio 2017 [Keyword: Sharing. Cagliari as Milan, the "Coworking" Spaces Multiply in the Historic Center]. Retrieved 19 October 2018 from: https://www.vistanet.it/cagliari/2017/07/21/parola-dordine-condivisione-crescono-gli-spazi-coworking-nelcentro-storico-cagliari/

MANZELLA, G.P. (2017). L'economia arancione. Storie e politiche della creatività [The Orange Economy. Stories and Policies of Creativity]. Soveria Mannelli: Il Rubettino.

MARIOTTI, I., CAROLINA, P., \& DI VITA, S. (2017). Coworking Spaces in Milan: Location Patterns and Urban Effects. Journal of Urban Technology, 24(3), 47-66. 
MERKEL, J. (2017). Coworking in the City. Ephemera, 15(1), 121-139.

ROODHOUSE, S. (2010). Cultural Quarters: Principles and Practice. Bristol (UK) and Chicago (USA): Intellect.

SCOTT, A.J. (2018). Residential Adjustment and Gentrification in Los Angeles, 2000-2015: Theoretical Arguments and Empirical Evidence. Urban Geography, DOI: 10.1080/02723638.2018.1500253

SEVTSUK, A., \& KALVO, R. (2017). City Form Lab, USA Patronage of Urban Commercial Clusters: A Network-Based Extension of the Huff Model for Balancing Location and Size. Environment and Planning B: Urban Analytics and City Science, DOI: 10.1177/2399808317721930

STEVENS, Q. (2015). Creative Milieux: How Urban Design Nurtures Creative Clusters. Journal of Urban Design, 20(1), 1-7, DOI: 10.1080/13574809.2015.981393

STEVENSON, D. (2014). Cities of Culture: A Global Perspective. Milton Park Oxon and New York: Routledge.

USAI, A. (2016). The Creative City: Cultural Policies and Urban Regeneration between Conservation and Development. Brussels: P.I.E. Peter Lang. 